\title{
Tek Taraflı Birliktelik (Kommensalizm), Karşılıklı Fayda Birlikteliği (Mutualizm) ve Asalaklık (Parazitizm) Üçgeninde İnsan-Doğa İlişkileri
}

\author{
SÜLEYMAN DÖNMEZ* \\ sdonmez@cu.edu.tr \\ ORCID ID: 0000-0003-4251-6665
}

\author{
MEHMET ALİ ÇELIK ${ }^{* *}$ \\ mehmet.ali.celikk@gmail.com \\ ORCID ID: 0000-0002-7729-6650
}

Öz: İnsan dışı doğada, canlılar arasında çeşitli birliktelik türleri mevcuttur. Bu etkileşimlerde, bazen ilişki içerisinde olan tüm canlılar fayda sağlarken kimi zaman ise canlllardan birisinin yarar, diğerinin zarar gördüğ̈̈ birliktelikler olmaktadır. Tüm bu ilişkilerin genel adına birlikte (simbiyoz) yaşam denilmektedir. Birlikte yaşam tek tarafl birliktelik (kommensalizm), karşılıkl fayda birlikteliği (mutualizm) ve asalaklı (parazitizm) olmak üzere üç farklı şekilde görülmektedir. Bu çalışma insan-doğa ilişkilerini, onto-epistemik manada logos ile tin arasındaki köprüleri kaldırmadan karşılıklı fayda birlikteliği bağlamında yeniden ele almaktadır. Nous-logos diyalektiğini tenden tine yolculuk ekseninde anlamayan kavrayış ekolojik krizin çözümünü, atmosferdeki karbon miktarının azaltılması, az enerji tüketen beyaz eşyalar kullanılması vs. gibi salt mekanik çözümlerde aramaktadır. Hâlbuki bu tarz mekanik, noustan yoksun logos anlayışına dayalı çözüm önerileri, asırlardır süregelen sorunu çözmek yerine, onu daha fazla derinleştirmektedir. Günümüzde insan-doğa ilişkilerinin daha fazla kriz üretmemesi için birlik esasında birliktelik anlayışını hâkim kılmak gerekmektedir. Doğa ancak bu yolla fark edilecek ve ahlâk üzerinden bir iletişim sağlanacaktır.

Anahtar Kelimeler: Ekolojik kriz, Etik, İnsan-doğa ilişkileri, Logos, Nous.

\section{Giriş}

Birçok çalışma, insan-doğa ilişkilerindeki bozulmanın eşik dönemi olarak sanayi devrimini işaret etmektedir ${ }^{1}$. Sanayi devrimi sonrasında, doğanın metalaştırılmas1, ekonomik üretim için ham madde olarak görülmesi ve aşırı bir şekilde tahrip edilmesinin sistemsel olduğu kadar fikri altyapısı vardır. Temelini doğadan alan modern bilim anlayışına göre, ekolojide mekanik bir şekilde işleyen parçaların tahrip edilmesinin ve yok edilmesinin diğer parçalara veya bütüne bir zararı olmamaktadır. Modern bilim anlayışı, çevreyi tahakküm altına almayı hedeflemiştir. Bu tahakküm,

\footnotetext{
* Prof. Dr., Çukurova Üniversitesi, İlahiyat Fakültesi, Felsefe Tarihi Ana Bilim Dalı.

** Dr., Kilis 7 Aralık Üniversitesi, Fen-Edebiyat Fakültesi, Coğrafya Bölümü.

1 Sezgin Ata, "Ekolojik Krize ve Nedenlerine Genel Bir Bakış", Ecotopianetwork sitesi, https://ecotopianetwork. wordpress.com/2010/03/03/ekolojik-krize-ve-nedenlerine-genel-bir-bakis-sezgin-ata/ (Erişim 1 Mart 2017). Aygül Kılınç, "Neoliberalizm Bağlamında Sürdürülebilir Kalkınmanın Merkez ve Çevre Ülkeler Açısından Değerlendirilmesi”, Afyon Kocatepe Üniversitesi İİBF Dergisi, 14/1 (2012), s.147.
} 
doğal kaynakların hoyratça tüketilmesi biçiminde tezahür ederken; sadece maddi dünyaya olan inanç, sürekli maddesel tüketimle mutlu ve umutlu bireylerden oluşan bir toplumu yaratarak, çevrenin tahribinde karşılıklı döngünün tamamlanmasına neden olmuştur² ${ }^{2}$ Modern düşünce insan-doğa ilişkilerinde doğayı cansız bir meta olarak sunmuştur. Böyle bir durumda insan-doğa ilişkileri etikten tamamıyla yoksundur.

Son birkaç asırdır ekolojik krizin patlak vermesine bağlı olarak birçok disiplin insan-doğa ilişkilerini yoğun bir şekilde ele almaktadırlar. Bu disiplinlerden birisi de etiktir. Geleneksel etik anlayışlarında insan merkeze alınırken, çoğu zaman insandoğa ilişkileri göz ardı edilmektedir. Bundan dolayı son dönemlerde birçok fikir insanı, insan-doğa ilişkilerini daha kapsamlı şekilde ele alan yeni bir etik anlayışın gerekliliğini savunmuştur. Bunlardan birisi Aldo Leopold'dur. Amerikalı filozof ekolojist Leopold etiğin çevreyi de içine alacak şekilde büyümesi gerektiğini belirtmiştir $^{3}$. Çevre aktivisti filozof Arne Naess ise Ekosofi kavramını kullanarak, ekoloji ile felsefeyi etik bağlamda birbirine yakınlaştırmıştır. Naess Ekosofi kavramını, 20. yy ile birlikte olumsuz etkileri gün yüzüne çıkan ekolojik krizin çözümü için kullanmıştır. Naess'e göre Ekosofi kavramı, kısaca ekolojik uyum ve dengenin felsefesi olarak belirtilmektedir ${ }^{4}$. Doğa hakkında fikirler beyan eden bir diğer önemli isim ise İngiliz filozof ve tarihçi Robin George Collingwood'dur. Collingwood klasik fiziğe dayanan mekanik felsefe anlayışının aksine doğanın döngüsel değil ilerleyici, makine değil canlı olduğunu ve bir erekselliği olduğunu görüşünü savunur ${ }^{5}$.

$\mathrm{Bu}$ çalışmada insan-doğa ilişkileri etik düzlemde ele alınmıştır. Bu düzlem, doğadaki birlikte yaşama biçimleri ile analoji kurularak sağlanmak istenmiştir. Zira birçok filozof doğa ile analoji kurarak yeni fikirler ortaya atmıştır. Bunlardan birisi de, doğadaki sınıfsız ve hiyerarşik olmayan organik düzen ile toplum arasında analoji kurarak ekolojik toplum paradigmasını inşâ eden Murray Bookchin'dir. Murray Bookchin doğa ile analoji kurarak inşâ ettiği Ekolojik Toplum Paradigmasının, her şeyden önce bir etik felsefesi (etik ahlak felsefesi demek) olduğunu iddia etmektedir 6 .

Doğa her zaman etik fikirlerin ortaya çıkmasına vesile olmamıştır. Kimi zaman bilimle uğraşan kişilerin ekoloji hakkındaki fikirleri farklı zamanlarda ve çeşitli şekillerde topluma uyarlanmıştır. Bunlardan birisi de, Charles Darwin'in Evrim Teorisidir. Darwin’in doğa hakkında ortaya attığı görüşlerden yola çıkarak, Sosyal Darwinizm akımı kurulmuştur. Sosyal Darwinizm kavramı ilk defa 1879'da, Oscar Scmidth tarafından ortaya atılmıştır. Darwin'in doğadaki canlılar arasında hiyerarşi olduğunu

\footnotetext{
2 Mehmet Özel, “Çağımız Çevre Sorunlarının Düşünsel Temelleri Üzerine Bir Yaklaşım”, Gazi Üniversitesi iktisadi ve İdari Bilimler Fakültesi Dergisi, 9/1 (2007), s.207.

3 Oya Beklan Çetin, "Derin Ekoloji Hareketi ve Çevre Etiği”, Ecotopianetwork sitesi. https://ecotopianetwork. wordpress.com/2009/12/21/derin-ekoloji-hareketi-ve-cevre-etigi/ (Erişim 6 Mart 2017).

4 Kubilay Aysevener, “İnsan ve Doğa İlişkisi Üzerine”, Filozoflar ve Düşündüren Sözleri internet sitesi, http:// dusundurensozler.blogspot.com.tr/2008/09/insan-ve-doa-ilikisi-zerine.html (Erişim 2 Mart 2017).

5 Mehmet Yalçın ve Fatma Ağgül, “Collingwood’un 'Doğa Tasarımı' ve Fen Eğitimi için Doğurguları”, Gazi Eğitim Fakültesi Dergisi, 29/2 (2009), s.301.

6 Mehmet Ali Çelik ve Ali Ekber Gülersoy, "Kaos Ortamında (Çağında) Mekân-İnsan Etkileşimine Bütüncül Bir Bakış: Ekolojik Toplum Paradigması”, FLSF (Felsefe ve Sosyal Bilimler Dergisi), 22 (2016), s.174.
} 
öne süren görüşlerinden yola çıkarak, insan ırklarının da hiyerarşik olduğunu ve bazı 1rkların üstün olduğu fikri savunulmuştur. Alman Nasyonal Sosyalizminin ve İtalyan Faşizminin Darwin'in biyoloji hakkındaki görüşlerinden etkilendiği bilinmektedir ${ }^{7}$.

$\mathrm{Bu}$ çalışma doğayı cansız bir manzara değil, canlı ve dinamik bir varlık olarak görmektedir. Bu bağlamda çalışmamızda, birçok filozofun yaptığı gibi doğa ile toplum arasında analoji kurulmaktadır. Böylelikle, doğadaki birlikte yaşam biçimlerini topluma uyarlayarak, insan-doğa ilişkilerinde yeni bir etik anlayışın ortaya konmaya çalışılmaktadır.

İnsan-dışı doğada yararlı ve zararlı birliktelikler olmak üzere iki türlü yaşam biçimi vardır. $\mathrm{Bu}$ çalışmada günümüzde insan doğa ilişkilerinin asalaklık bağlamında olduğu vurgulanırken, doğadaki yararlı birlikteliklerin toplumda hâkim kılınması gerektiği savunulmaktadır. Çalışmamızda "insan ile doğa arasında yeni bir etik iletişim gerekir" ile vurgulanmak istenen "karşılıklı fayda birlikteliğgi" iddiası temelindeki etik ilişki, yalnızca maddi temele dayanmamaktadır. Bu çalışma, karşılıklı fayda birlikteliğini maddi çerçevede çıkara dayalı bir birliktelik olarak değil, manadan maddeye bakan bir birlik mantığı üzerinden kurmaya çalışmaktadır. Esasen bu bir fayda birlikteliğinden öte, ötekini emanet olarak gören bir anlayıştır. Karşılıklı fayda ise, kaçınılmaz olarak kendiliğinden doğmaktadır. Burada vurgulanmak istenen, hem maddi hem de tinsel anlamdaki karşılıklı faydada sağlanan ahlâki iletişim biçimidir.

Bu çalışmada ilk olarak, insan-dışı doğada canlıların birbiri ile olan etkileşimlerine değinilecektir. Daha sonra, insan dışı doğa ile toplum arasındaki ilişkilerin evriminin geçmişten günümüze nasıl olduğu konusundan bahsedilecektir. Son olarak insan-doğa ilişkilerinde meydana gelen yabancılaşma ve bunun sonucunda ortaya çıkan küresel ekolojik kriz meselesine değinilecektir. Aynı zamanda insan-doğa ilişkilerinin onto-epistemik anlayışla karşılıklı fayda birlikteliği ekseninde yeniden inşası önerilecektir. Bu birliktelik, salt doğal bir işleyişin ötesinde doğala tahakküm etmeden doğalla buluşma ve birlikte olma anlamına gelmektedir.

$\mathrm{Bu}$ çalışma, temelde şu sorunun cevabını aramaktadır: Cemil Meriç’in Yabancılaşma, Ahmet İnam’ın Kokuşma ve Hilmi Ziya Ülken’in Makine Adam Düzeni olarak kavramsallaştırdığı mevcut toplumsal durum ile ekolojik kriz arasında nasıl bir ilişki vardir?

$\mathrm{Bu}$ sorunun cevabına ulaşmak için ilk olarak Ekolojik krizin neliğinden kısaca bahsetmek gerekir. Niceliksel büyüme odaklı kapitalizm (sanayi uygulamaları için yeni teknolojiler yaratılması vb.), doğal denge ve döngülerin alt üst olmasına (toprağın, havanın, suyun ve diğer canlıların olumsuz etkilenmesine) sebep olmuştur. Ekolojik kriz, son iki asırdır baş döndürücü bir hızla değiştirilen doğal ortam şartlarına ayak uyduramayan canlıların ayıklanmasına, başka bir deyişle yok olmasına neden olmaktadır. Sürekli ekonomik büyümenin sonuçlarını ifade eden bu süreç, sınır değerlerin aşılmasını, ekolojik krizi, yani organik toplum yapısından

7 İsmail Dursunoğlu, "Sosyal Darwinizm”, Karabük Üniversitesi Sosyal Bilimler Enstitüsü Dergisi, 6/1 (2016), s.210. 
uzaklaşmayı ifade etmektedir. Doğal ortamın kurallarını dikkate almayan, madde-enerji dönüşümlerinin önüne geçmeye çalışan modern insan, kendisine ikinci bir doğa oluştururken, birçok canlının doğal ortamlarından izole olmasına, yok olmasına, doğal döngülerin (besin döngüsü, su döngüsü, azot döngüsü vs.) aksamasına yol açmıştır. Nitekim kitlesel balık ölümleri, buzul alanlarındaki heyelanlar; çığlar, seller, ormanların yok olması, endemik türlerin ortadan kalkması, $\mathrm{CO}^{2}$ miktarındaki dramatik artı̧lar; ozon tabakasındaki seyrelme, deri kanseri vakaları vb. söz konusu krizin sonuçlarını yansıtmaktadır . Dolayısıyla ekolojik kriz meselesi sahip olduğu ölçek ve gelecekle ilgili oluşu sebebiyle, diğer tüm sorunlardan farklıdır. Bu sorunla başa çıkmak için gerekli olan şey, savaştaymışçasına seferberlik ilan etmektir?.

Bu seferberlik, insan-doğa ilişkilerinin düzenlenmesi kadar toplumda bireyler arasındaki ilişkilerinin düzenlenmesini elzem kılmaktadır. Çünkü kendisine yabancılaşan insan, doğal döngüleri ve ekosistem zincirindeki hassas dengeyi anlamakta zorlanacaktır.

\section{Kavramsal Çerçeve}

\section{a) Doğadaki Birlikte (Simbiyoz) Yaşam Biçimleri}

İnsan-dışı doğada bazı canlılar beslenme ihtiyaçlarını tek başlarına karşılayamazlar. Bundan dolayı başka canlılarla birlikte yaşarlar. Böylelikle beslenme yoluyla iki canlı türü birbiriyle etkileşime geçer. İki organizmanın tekinin ya da her ikisinin varlığını sürdürmesi için bir arada bulunmalarına birlikte yaşam denilmektedir. Tek taraflı birliktelik (kommensalizm), karşılıklı fayda birlikteliği (mutualizm) ve asalaklık (parazitizm) temelinde gelişen etkileşimler, insan-dışı doğadaki canlıların birbirleri ile olan ilişki biçimleridir ${ }^{10}$. İnsan-dışı doğada ilişkiler yararlı ve zararlı birliktelikler olmak üzere 2 kategoride ele alınmaktadır. Yararlı birliktelikler; tek taraflı birliktelik ve karşılıklı fayda birlikteliği olmak üzere 2'ye ayrılmaktadır. Tek taraflı birliktelikte, etkileşim içerisinde olan iki canlıdan birisi (konuk) fayda sağlarken öteki canlı (konak) herhangi bir yarar veya zarar görmemektedir. Karşlıklı fayda birlikteliği ise beslenme yoluyla ilişki içerisinde olan iki canlının da fayda sağlaması durumudur. $\mathrm{Bu}$ etkileşim türünde ilişki içerisinde olan canlıların birbirinden ayrılması durumunda, her ikisi de zarar görmektedir. İnsan-dışı doğadaki bir başka ilişki biçimi asalaklıktır. Zararlı birliktelik olarak adlandırılan bu ilişki biçiminde bir canlı fayda sağlarken, öteki zarar görmektedir (Şekil 1).

Toplum ve doğadaki ilişkilerin çoğunun temelinde beslenme bulunur. Beslenme vasıtasıyla kurulan ilişki biçimleri bazen karşılıklı fayda sağlarken kimi zaman ise tek bir canlı fayda sağlamaktadır. Bazı durumlarda ise bir canlı fayda sağlarken diğer canlı zarar görmektedir. Söz konusu simbiyotik ilişki biçimleri, insan ile doğa arasındaki ilişkilerde de geçerlidir. Bu bağlamda değerlendirildiğinde, insan-dışı doğadaki canlılar arasındaki ilişkiler ile toplumsal ilişkiler birçok yönden benzerlik göstermektedir.

8 Çelik ve Gülersoy “Kaos Ortamında (Çağında) Mekân-İnsan..., s.165.

9 Anthony Giddens, İklim Değişimi ve Siyaseti, çev. Erhan Baltac1, İstanbul: Phoenix, 2013, s.12.

10 Ahmet Kocataş, Ekoloji: Çevre Biyolojisi, Bursa: Dora Basım, 2014, s.202-204. 


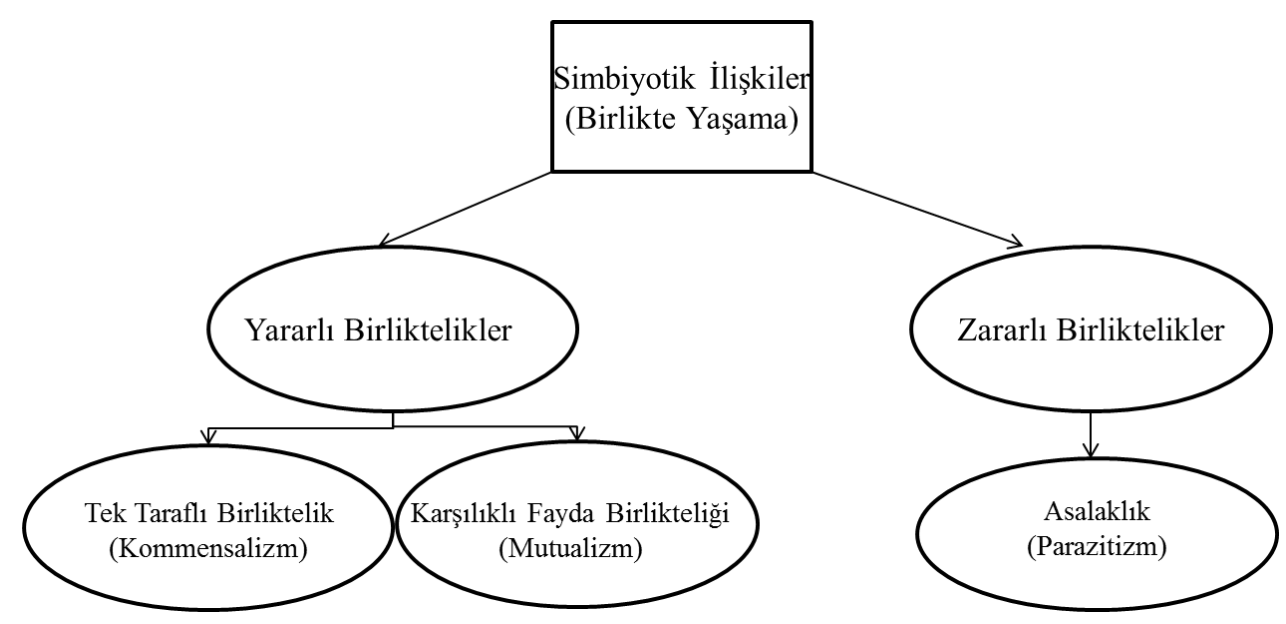

Şekil 1. İnsan-dışı Doğada Beslenme Yoluyla Kurulan İlişki Biçimleri

İnsan ile doğa arasındaki ilişkilerin karşılıklı fayda temelinde geliştiği durumlarda, insan ve doğa zarar görmemektedir. İnsan ile doğa arasındaki ilişkilerin yararlı birliktelik ekseninden, zararlı birlikteliğe kayması durumunda ekolojik sömürü başlamaktadır. Bu durumda, hem insan hem de doğa zarar görmektedir. Asalaklık temelinde gelişen ilişkilerin kaynağı ise insan ile insan arasındaki ilişkilerin yararlı birliktelik özünden zararlı birlikteliğe evrilmesi ile başlamıştır. Bir başka ifade ile toplumda bireylerin karşılıklı fayda birlikteliği temelinde olan ilişkileri, mevcut kapitalist sistem ile bir tarafın diğerine zarar vermesi ve onu sömürmek suretiyle büyümesi temeline dönüşünce ilişkiler asalaklık düzlemine indirgenmektedir.

Asalaklık olarak adlandırılan sömürücü ve metalaştırıcı bu sistemin bakış açısına göre insanın ve doğal unsurların bizatihi kendi ontolojilerinden kaynaklanan değerleri olduğu kabulü yoktur. Buna göre, çevresel değerleri korumanın yegâne gerekçesi sistemin daha fazla büyümesini sağlamaktır. Diğer bir ifadeyle "korunmaya değer olan", ancak sistem için faydalı olandır ${ }^{11}$.

Çıkar ve kâr üzerine şekillenen toplum- doğa ilişkileri, toplumu var eden ahlaki ve vicdani değerlerin içini boşaltmış ve yozlaştırmıştır. Hareket alanı daralan ve doğası gereği özgür olması gereken bireyler, yaratııılığını, vicdanını ve birlikte yaşam ideallerini yitirmiştir. Başka bir deyişle insanı insan yapan özellikler parçalara ayrılmış, tanınmaz hale gelmiştir. Böyle bireylerden oluşan toplumda ekolojik ve toplumsal bilinç, sorumluluk duygusu ve vicdanın gelişmesi oldukça zordur.

En küçük fenomenleri bile "aşağı" ve "üstün" kavramları etrafında inşa etmiş olan bu hiyerarşik sistem organik duyarlılıktan (yararlı birliktelik) uzaktır ${ }^{12}$. Bu sistemde ekolojiye dair insan tasarımları hiyerarşik ve sanaldır. Mevcut sistem canlıları faydalı birliktelik esasından çıkararak, onları birbirine düşman piramitler şeklinde derecelendirir. Halbuki bireyler ve şeyler birbirinden daha iyi ya da kötü değildir. Hepsi

11 Coşkun Karaca, “Çevre, İnsan ve Etik Çerçevesinde Çevre Sorunlarına ve Çözümlerine Yönelik Yaklaşımlar”, Çukurova Üniversitesi İİB Dergisi, 11/1 (2007), s.21.

12 Süleyman Dönmez ve Mehmet Ali Çelik, "Ekolojik Krizin Kaynağını İnsan Olarak Gören İndirgemeci Anlayışın Eleştirisi”, Çukurova Üniversitesi İlahiyat Fakültesi Dergisi, 16/2 (2016), s.46. 
kendi içerisinde değerlendirilir ve eşsiz niteliklerinden ötürü değer görür. Dünya pek çok bileşenin bir araya gelmesinden oluşan bir yapı olarak algılanır ve onun bütünlüğü ve uyumu için her parça vazgeçilmez önemdedir ${ }^{13}$.

\section{b) Onto-Epistemik Akıl}

İnsanlık son birkaç asırdır, gezegenimizde olup bitenleri anlamlandırmada ve çözüm üretmede sıkıntı çekmektedir ${ }^{14}$. Bu sorunlardan birisi, ekolojik krizdir. Başlarda ekolojik kriz karşısında insanlığın tavrı görmezden gelmek ve yok saymak şeklinde olmuştur $^{15}$. Bu tavır sorunu daha fazla derinleştirmiştir. 21. yy derinleşen ekolojik kriz karşısında, farklı bakış açıları ve çözüm önerilerini zorunlu kılmıştır. Bu çalışmada ele alınan bakış açılarından birisi onto-epistemik akıldır. Onto-epistemik akıl, insanlığg hiç olmadığı kadar derin krizler içerisine sokan mevcut aklın, ahlakın, bilimin ve varlık kavrayışının yeniden inşâsı için bir metodolojidir. Varolanı esas alır. Varolanın çözümlenmesine dayalı bir inşâyı hedefler. Öncelik varolandır. Bilgi ise varolanın bilgisidir. Lakin varolanın bilgisine sahip olunurken takınılan tavır, salt bilimsel ya da tamamen ruhçu değil, bütüncül ve dengeleyicidir. Hasılı onto-epistemik akıl bir metottur. Bu metot ile daha güçlü sermayeye odaklanan kontrolsüz teknoloji anlayışına, doğayı hammadde olarak gören mekanik bakışa, kirlenmiş ve içi boşaltılmış zihinlere karşı alternatif bir bakış açısı geliştirilmek istenmektedir.

Onto-epistemik akıl, felsefî olarak Aristotelesçi düşünürlerin varlık temelli bilgi anlayışını temel alır. Ama bu anlayışa yeni bir yorum getirilir. Buna göre, bu yaklaşımda zihin sözcügü yalnızca aklın kavrama ve bilme edimine dayanmaz. Burada zihin kavramı, vicdanî duyuşu içerisine alan bir ruha da sahiptir. Bu nedenle onto-epistemik akıl köken olarak ontik, tezahür olarak epistemiktir. Bir başka deyişle; düşünüş, duyuş, bilgi ve biliş asıl olan ontik aklın epistemik görünümüdür ${ }^{16}$. Kısacası onto-epistemik düzlem ile akıl ve ruh bütünleşmesi sağlanmaktadır. Böylelikle varlığa yalnızca bilme amaçlı -salt epistemik- değil onda bir ruhun -mananın- var olduğunu bilerek yaklaşmak ve onunla empati kurmak gerektiği vurgulanmaktadır. Esasen meseleyi bu tarz açmak, onto-etik bir tavrı da içerir. Ancak sorunun bilimsel çerçevede ele alınması bizi onto-epistemik bir zeminde kalmaya zorlamaktadır. $\mathrm{Bu}$ çerçevede biz, mesela, Hindistan'da yüksek mahkemenin Hint halkı tarafından kutsal sayılan Ganj ve Yamuna nehirlerinin hukuki olarak "gerçek kişi” statüsünde değerlendirilmesine karar vermesini ${ }^{17}$ onto-epistemik aklın bir tezahürü olarak görebiliyoruz. Aynı zamanda bunun etik bir yaklaşım olduğunu da görüyoruz.

$\mathrm{Bu}$ manada insan-doğa ilişkilerini etik düzlemde yeniden tesis etmek için Hindistan'daki örneğin yanı sıra kendi coğrafyamıza ve tarihimize bakmak önemlidir. Bu

13 Murray Bookchin, Özgürlüğün Ekolojisi: Hiyerarşinin Ortaya Çıkışı ve Çözülüşü, çev. Mustafa Kemal Coşkun, İstanbul: Sümer Yayıncilık, 2013, s.118.

14 Süleyman Dönmez, Keşfedilmeyi Bekleyen Medeniyet: Felsefenin Batı Dışı Referanslarına Eleştirel Bir Katkı, Adana: Karahan Kitabevi, 2015, s.27.

15 Mehmet Ali Çelik vd., "Yerelden Küresele Evrilen Ekolojik Krizin Psiko-Sosyal ve Politik Ekolojik Açllardan İrdelenmesi”, FLSF (Felsefe ve Sosyal Bilimler Dergisi), 23 (2017), s.110.

16 Dönmez, Keşfedilmeyi Bekleyen Medeniyet, s.32.

17 “Ganj nehri artık insan haklarına sahip”, BBC Türkçe internet sayfası, 23 Mart 2017, http://www.bbc.com/ turkce/haberler-dunya-39342778 (Erişim 5 Haziran 2017). 
noktada onto-epistemik aklı daha iyi anlamak için İslam kültüründen örnekler de verilebilir. İslam Peygamberi, “İlim Çin'de de olsa gidip alınız” demektedir. Fakat buradaki anlayış günümüzün varlığı anlam değerden soyutlayan mekanik ve maddeci bilim kavrayışından çok uzak görünmektedir. Günümüz bilim anlayışı insanı kendini kendine yeterli olarak görür. Daha çok hükmetme, değiştirme ve kontrol etme mantığı ile hareket eder. Bu anlayış çevresel krizin önemli bir kaynağıdır. Hâlbuki İslam düşüncesinde insanın dışa dönük eylemlerini insanoğlunun içe dönük doğasıyla bağdaştırılarak, esenliğe ve sağlıklı bir hayat tarzına varan bir yol çizilir ${ }^{18}$. Bu durum çalışmamızda vurgulanan onto-etik temeldeki tavrın İslam kültür ve düşüncesindeki dışavurumudur. İnsan-Doğa ilişkileri birçok Müslüman düşünürce tarafından ele almış bir husustur. Örneğin onlardan birisi Mevlana Celaleddin Rumî̀dir. Mevlana ekolojik krizin patlak vermesinden asırlar önce insan-doğa ilişkileri hakkında Mesnevi'de şiirsel bir ifade ile fikir beyan etmiştir. Mevlana, doğaya ilişkin coşkulu bir iyimserlik taşımaktadır. Mevlana'ya göre, doğa bizim yol arkadaşımızdır ve bütün parçaları tıpkı insanlar gibi canlıdır. Bundan dolayı doğayı yakından tanımamız ve kavramamız gerekmektedir ${ }^{19}$. Mevlana’nın bu görüşleri, çalışmamızda karşılıklı fayda birlikteliği ekseninde yeniden inşâ edilmek istenen insan-doğa ilişkilerinin etik temelini oluşturmaktadır.

Günümüzde insan-doğa ilişkilerinin daha fazla kriz üretmemesi için birlik esasında birliktelik anlayışını hâkim kılmak gerekmektedir. Birlikten birliktelik ya da birliktelikten birlik idrak edildiğinde, birlikteliğin yolu açılacaktır. Öteki yani doğa ancak bu yolla fark edilecek ve etik üzerinden bir iletişim sağlanacaktır. Bu durum onto-etik bir tavırdır. Onto-etik tavır, modern süreçle içine düşülen ayrıştırıcı bakışları yeniden bütünleyebilme girişimidir ve varlığı, yani hakikati esas alır. Varlıktan hareketle düşünceye ulaşır. Hareketin yönünü tayin etmek suretiyle değeri yaratır. $\mathrm{Bu}$ çalışmada varlığı canlı olarak algılayan ve kendinde değer atfeden bir bilgi kuramsal yaklaşımın, ekolojik krizin çözümünde önemli bir metot olacağı düşünülmektedir.

\section{Hilmi Ziya Ülken'in Makine Adam Düzeni, Cemil Meriç'in Yabancılaşma ve Ahmet İnam'ın Kokuşma Olarak Belirttiği Sistemde İnsan-Doğa İlişkileri}

Maddeyi anlamak için atoma, toplumu da anlamak için bireye bakmak önemlidir. Atomun yapısı değişince madde değişir. Birey değişince de toplum değişir. Birey şehri inşâ etti fakat şehir de yeni bir birey prototipi inşa etti. Kentsel ortam, insanın içinde bulunduğu dünyayı kendi arzuladığı şekle sokma çabasının genel anlamda en başarılı anını temsil eder. Fakat insanın yarattığı dünya olan kent, bundan böyle doğaya yabancılaşarak, yaşamaya mahkûm olduğu alan halini almıştır ${ }^{20}$.

Mevcut sistem insanları doğadan uzaklaştırarak, kentlerde yaşamaya mecbur bırakmaktadır. Mevcut sistemde gelişmişliğin göstergesi, kentlerde yaşayan insanların

18 Sadiye Hawar Han Çişti, “Fıtrat: İnsanlar ve Çevre İçin Bir İslâmi Model”, Richard C. Foltz, Frederick M. Denny ve Azizan Baharuddin (der.), İslam ve Ekoloji: Bahşedilmiş Bir Emanet, çev. Nurettin Elhüseyni, İstanbul: Oğlak Yayıncılık, 2007, s.91-92.

19 L. Clarke, "Celaleddin Rumînin Mesnevîsinde Doğa”, Richard C. Foltz, Frederick M. Denny ve Azizan Baharuddin (der.), İslam ve Ekoloji: Bahşedilmiş Bir Emanet, çev. Nurettin Elhüseyni, İstanbul: Oğlak Yayıncılık, 2007, s.83.

20 David Harvey, Umut Mekanları, çev. Zeynep Gambetti, İstanbul: Metis Yayınları, 2008, s.95. 
niceliğidir. Bir ülkede ya da bölgede ekonomik gelişmişliğin temel ölçütü olarak, tarımla uğraşan nüfusun azalması gösterilmektedir. Buna mukabil hizmet sektörü ve sanayi ekonomisinde meydana gelen artış o bölgenin ekonomik olarak geliştiğini işaret etmektedir. Bu durum, doğaya yabancılaşmayı ve nüfusun kentlere yığılmasını teşvik etmektedir. Çünkü nüfus miktarının ne kadar büyük bir kısmı hizmet ve sanayi sektöründe çalışırsa, o ülke o oranda gelişmiş demektir. Bu sistem içerisinde varoluş bu temel prensibe dayanmaktadır.

İnsan doğaya yabancılaşmakla kalmamış başta kendisine yabancılaşmıştır. Bu yabancılaşma aslında kendi özünden ontolojik olarak kopmanın adıdır. Kendi özünden ontolojik olarak kopan birey ve toplum, bu çerçevede ilişkilerini ve kurumlarını da başkalaştırmıştır. Bu başkalaşma sonucunda insanın-insanla ve insanın-toplumla olan ilişkilerinde etik bozulma meydana gelmiştir.

Ahmet İnam insan ilişkilerinde meydana gelen etik bozulmayı (yararlı birliktelik özünden zararlı birliktelik eksenine kayma) kokuşma diye kavramsallaştırmaktadır. Ahmet İnam toplumdaki ilişkilerin kokuşmasını şu şekilde ifade etmektedir ${ }^{21}$ :

İnsanların birbirlerini insan yerine koymadığı, birbirlerini damgalayarak kalıplar içinde önyargılarla gördügü bir dünyada yaşam kokuşur! Birbirlerini darlaştırarak, kafalarındaki çerçeveler içine sıkıştırıp gören; güveni, sevgiyi, saygıyı, yaratmayı, canlılığı, sevinci, keşfi, özgünü arama beklentilerini yaşayamayan insanların oluşturduğu toplum kokuşur! Birbirini kullanmaya, sömürmeye çalışan, içten anlama isteği yerine, düzeni sürdürmek için gerekli davranışlarda bulunmayı, dıştan uyumlu görüntüler vermeyi seçen, kendi yarattıkları daracık dünyalarında konforun, ekonominin ve teknolojinin rahatlığıyla sı̆̆lı̆̆ı seçen insanların ilişkileri kokuşur! Ne birbirlerini ne de kendi içlerini göremeyen insanların başta doğaya, evrene, bilgilerine, duygularına, sezgilerine düşüncelerine, bedenlerine, içinde yaşadıkları kültürel, ahlaksal, toplumsal, siyasal, ekonomik düzene bakışları kokuşur.

Bir başka ifade ile toplumsal kokuşma ile ifade edilen birlikte yaşam biçiminin özünü kaybetmesidir. Birlikte yaşamın özünde bir canlı fayda sağlarken diğer canlı da fayda görmelidir. Öteki canlı yarar görmüyorsa bile en azından zarar görmemelidir. Hâlbuki günümüzde gerek toplumsal ilişkilerde gerekse de insan-doğa ilişkilerinde bir tarafın büyümesi diğer tarafın yok olması üzerinden gerçekleşmektedir. Cemil Meriç'in deyimiyle çağdaş insan köklerinden kopmuş bir ağaçtır, hem kendine yabancı hem tabiata. Ekolojik kriz tamda böyle bir ortamda filizlenmiştir ${ }^{22}$.

İnsan da doğadaki diğer canlılar da artık bir eşyadır. Fayda sağladığı ölçüde değer gören bir metadır. Bu açıdan bakıldığında insan sadece doğaya yabancılaşmamış, tüm canlı alemine yabancılaşmıştır. Dolayısıyla böyle bir durumda ekolojik kriz ve toplumsal krizi birbirinden ayırmaktan öte bir bütün olarak görmek gerekir. Ve tüm bu sorunların adına biyosferik kokuşma denilebilir.

21 Ahmet İnam, “Karşılaşma Ahlakı Üstüne Bazı Düşünceler”, Prof. Dr. Ahmet İnam’ın kişisel sayfası, http://phil. metu.edu.tr/ahmet-inam/karsilasma.htm (Erişim 8 Şubat 2017).

22 Cemil Meriç, Bir Dünyanın Eşiğinde, İstanbul: İletişim Yayınları, 1994, s.19. 
Doğadan koparak şehirlerde yaşayan insanın doğa hakkındaki bilgisi de düşmektedir. Doğadaki her bir canlının önemini, ekolojik denge ve döngüdeki yerini anlayamamaktadır. Bu duruma etik kopma da eklenince; insan sadece kendisine faydalı olan canlılara değer vermektedir. Kendisine somut olarak herhangi bir fayda sağlamayan canlıları ise, yok etmektedir. Kısacası insanın doğadan kopuşu ilk olarak ontolojik manada gerçekleşmiştir. Daha sonra, epistemik son olarak ise etik kopuş gerçekleşmektedir. Ontolojik kopuş, insanın doğa ile vicdani ve etik bağları koparırken, epistemik kopuş ekolojik bilinci yok etmiştir. Etik değerlerden yoksun kent ortamında, insan artık bir metadır.

$\mathrm{Bu}$ yönüyle insan artık aklı, duyguları ve vicdanı olan bir canlı olmaktan öte makine adam olma yolundadır. Hilmi Ziya Ülken Aşk Ahlakı kitabında hür insan olmayı "makine-adam" olmamak, makineleşmenin içinde kendini kaybetmemek olarak tanımlar ${ }^{23}$. Ne yazık ki, çağımızda ilk olarak insan makinenin dişlisi olmuştur daha sonra ise doğayı makinenin hammaddesi haline dönüştürmüştür. Bu açıdan bakıldığında, ekolojik krizin toplumsal bozulma ile olan yakın ilişkisi idrak edilmektedir. Bu haliyle ekolojik kriz bir toplumsal krizdir denilebilir. Çünkü insana acımayan insan, ontolojik, epistemik ve etik bağlamda daha fazla koptuğu doğaya hiçbir şekilde yaşam şansı tanımaz. İnsanın insana olan yakınlaşması aynı zamanda insanın doğaya olan yakınlaşması anlamına gelmektedir. Bu açıdan bakıldığında, insanı insana yakınlaştırmak insanlar arasındaki ilişkiyi çıkar ve fayda ölçeğinden kurtarmak gerekir.

İnsanın doğaya yabancılaşması, ilk olarak ontolojik daha sonra ise epistemik ve etik bağlamda kopma yaratmıştır. Günümüzde ontolojik, epistemik ve etik olarak doğadan kopan insan, ekolojik kriz meselesinden çıkış yolu üretememektedir. Çünkü doğadan ontolojik olarak kopan insan, ekoloji hakkında bilgi eksikliğine düşmüş ve tek pusula olarak tekno-bilimsel yöntemlerle yani noustan yoksu logosla ekolojik krizi çözmeyi ummaktadır. Logos, bütünün peşindedir. Tinsel düzlemde ona birlik denilir. Değişen çoklukların ardındaki değişmeyen birliğin aranmasıdır. Logos ona görünen teklikleri bir araya getirerek yapılan hesapla ulaşılabileceğini düşünür. Yani logos anlayış modern bilimlerde olduğu gibi atomlardan maddeyi anlamayı amaçlamaktadır. Halbuki bütün parçaların toplamından daha öte bir anlam içerir. Logos, bu durumu ne izah edebilir ne de inkâr. Çokluğun ardındaki birlik, tinsel düzleme geçmeden kavranamaz. Çünkü birlik, logosla değil, nous ile idrak edilebilir. Biri tensel (logos), diğeri tinseldir (nous). Bu bağlamda değerlendirildiğinde, İnsan-doğa ilişkilerini, onto-epistemik manada logos ile tin arasındaki köprüleri kaldırmadan karşılıklı fayda birlikteliği bağlamında yeniden ele almak gerekmektedir. Nous-logos diyalektiğini tenden tine yolculuk ekseninde anlamayan kavrayış, insanı ve doğayı sıradanlaştırır, nesneleştirir ve maddeleştirir. Böylelikle insan ontolojik olarak doğa ile arasına duvar çekmiş olur ${ }^{24}$.

Çağımızın büyük sorunu: parçayı incelerken, bütünü kaçırmaktır. Tarihteki örnekler ekolojik kriz meselesinin tek bir yöntemle çözülemeyeceğini göstermiştir. Tek 
bir yöntemle çözüm arayışı; sorunlar yumağının bir düğümünü çözerken, başka bir düğüm örmektedir. Mesela söz konusu krizin yalnızca bilimsel yöntemler ile çözülemeyeceği tarihsel pratiklerden anlaşılmaktadır. "Ozon gazının delinmesi” olarak bilinen soruna getirilen çözüm bu meselenin yalnızca bilimsel yöntemler ile çözülemeyeceğine iyi bir örnektir. Ozon gazının incelmesi ya da seyrelmesi olarak bilinen olay, günümüzde artık tartışılmamaktadır. Çünkü 1986 yılında Montreal Protokolü ile ozonu kemiren gazın kloroflorokarbon olduğu anlaşılmıştır ve bu gazın sanayide kullanımı yasaklanmıştır. Kloroflorokarbon gazının yasaklanması sonucunda ozon gazının incelmesi veya seyrelmesi sorunu çözülmüştür. Ancak kloroflorokarbon yerine halokarbonların kullanılması sonucunda nur topu gibi yeni bir sorun dünya gündemine damgasını vurmuştur: küresel iklim değişimi. Nitekim halokarbon kullanımının atmosferdeki sera gazı etkisini arttırdığ ${ }_{1}$ bazı çalışmalarla anlaşılmıştır25 .

Kısacası, şu anda karşımızda duran muazzam bozulmalar göz önüne alındığında, çağımız, sorunlarla başa çıkmak için daha kapsamlı ve kavrayışl1- bilimsel olduğu kadar toplumsal- bir bilgi bütününü gerektiriyor. Önceki bilimsel ve toplumsal teorilerin kazanımlarından vazgeçmeden, doğal dünya ile ilişkimizin daha kapsamlı bir eleştirel analizini geliştirmemiz gerekiyor. Doğa ile toplum arasındaki bariz "çelişkiler"in ortaya koyduğu ciddi sorunlara yönelik daha yapıcı bir yaklaşımın temellerini araştırmalıyız. Artık daha geleneksel bilimlerin olguları parçalara ayırma ve bu parçaları inceleme eğilimlerinin tutsağı olma lüksüne sahip değiliz. Olguları birleştirmemiz, birbiriyle ilişkilendirmemiz ve onları özgüllüklerinin yanı sıra bütünlükleri içinde görmemiz gerekiyor. Bu yol ekolojik kriz sorunsalından kurtuluş konusunda ilerlemenin önünü açabilir. Aksi takdirde, sorun daha fazla derinleşerek, insanı mahşeri bir sıfır noktasına taşıyacaktır ${ }^{26}$.

\section{Sonuç}

İnsan-doğa ilişkilerinin temelinde olması gereken etik anlayış, son birkaç asırdır ortadan kalkmıştır. Bunun sonucunda doğa metalaşmış, cansız bir nesne halini almış ve ekonomik büyümenin ham maddesi olarak görülmüştür. İnsan-doğa ilişkilerinde meydana gelen sömürücü ilişki anlayışı doğada var olan zararlı ilişki biçimine benzemektedir. Doğada bir canlının yaşaması diğer canlının yok olması şeklinde sonuçlanan asalaklık temelindeki ilişki biçimi sürdürülebilir değildir.

Günümüzde insan-doğa ilişkilerinin ahlak esasından birlikten birlikteliği kurarak kendiliğinden gelen yararlı birliktelik halini alması gerekmektedir. Karşılıklı fayda birlikteliği temelinde ilişkiler, doğadaki denge ve döngülerin devamı için büyük önem arz etmektedir. Ama bunun maddi bir birliktelik esasında kurulması doğayı tahribe kolayca evrilebilmektedir. Bu ilişki biçiminin toplumda tesis edilmesi ancak yeni bir etik anlayışla mümkündür. Artık insan-doğa ilişkileri, onto-epistemik manada logos ile tin (tin ile logos) arasındaki köprüleri kaldırmadan karşılıklısız fayda birlikteliği bağlamında yeniden ele alınmalıdır. Nous-logos diyalektiğini tenden tine yolculuk ekseninde anlamayan kavrayış ekolojik krizin çözümünü, atmosferdeki karbon mik- 
tarının azaltılması, az enerji tüketen beyaz eşyalar kullanılması vs. gibi salt mekanik çözümlerde aramaktadır. Hâlbuki bu tarz mekanik, noustan yoksun logos anlayışına dayalı çözüm önerileri, asırlardır süregelen ekolojik kriz sorunu çözmek yerine, onu daha fazla derinleştirmektedir. Bir başka ifade ile varlıkla (doğa) bilginin arası açlınca değerlerin evrenselliği temellendirilememektedir. Ontik gerçeğin epistemik gerçekliğe dönüştürülerek geçici çözümler üretme çabaları sorunu çözmemektedir.

Kısacası bu çalışma, küresel ekolojik krizden çıkış için, insan-doğa ilişkilerinin onto-epistemik düzlemde yeniden ele alınmasını önermektedir. Bu bağlamda değerlendirildiğinde, kontrolsüz gelişen teknoloji, kirlenen bilgi ve zihin dünyası ile küresel ekolojik krizin kaynağını teşkil eden sebepler birbirinden farklı değildir. Söz konusu sorunların çözümü için mekanik anlayışın önerileri ile pozitivist deneyci yaklaşımlar yetersiz kalmaktadır. Modern sonrası dönemin inşâcılı̆̆ı da söz konusu devasa sorunlara çözüm olabilmiş değildir.

\section{Kaynaklar}

Ahmet İnam. “Karşılaşma Ahlakı Üstüne Bazı Düşünceler”. Prof. Dr. Ahmet İnam’ın kişisel sayfası. http://phil.metu.edu.tr/ahmet-inam/karsilasma.htm (Erişim 8 Şubat 2017).

Ata, Sezgin. "Ekolojik Krize Ve Nedenlerine Genel Bir Bakış”. Ecotopianetwork sitesi. https://ecotopianetwork.wordpress.com/2010/03/03/ekolojik-krize-venedenlerine-genel-bir-bakis-sezgin-ata (Erişim 1 Mart 2017).

Aysevener, Kubilay. “İnsan ve Doğa İlişkisi Üzerine”. Filozoflar ve Düşündüren Sözleri internet sitesi. http://dusundurensozler.blogspot.com.tr/2008/09/insanve-doa-ilikisi-zerine.html (Erişim 2 Mart 2017).

Bookchin, Murray. Özgürlüğün Ekolojisi: Hiyerarşinin Ortaya Çıkışı ve Çözülüşü. Çev. Mustafa Kemal Coşkun. İstanbul: Sümer Yayıncılık, 2013.

Clarke, L. “Celaleddin Rumînnin Mesnevîssinde Doğa”. Richard C. Foltz, Frederick M. Denny ve Azizan Baharuddin (der.). İslam ve Ekoloji: Bahşedilmiş Bir Emanet. Çev. Nurettin Elhüseyni. İstanbul: Oğlak Yayıncılık, 2007: 67-87.

Çelik, Mehmet Ali ve Ali Ekber Gülersoy. "Kaos Ortamında (Çağında) Mekân-İnsan Etkileşimine Bütüncül Bir Bakış: Ekolojik Toplum Paradigması”. FLSF (Felsefe ve Sosyal Bilimler Dergisi). 22 (2016): 163-183.

Çelik, Mehmet Ali, Ali Ekber Gülersoy, Şadi İdem ve Çağdaş Dedeoğlu. "Yerelden Küresele Evrilen Ekolojik Krizin Psiko-Sosyal ve Politik Ekolojik Açılardan İrdelenmesi”. FLSF (Felsefe ve Sosyal Bilimler Dergisi). 23 (2017): 105-121.

Çetin, Oya Beklan. "Derin Ekoloji Hareketi Ve Çevre Etiği”. Ecotopianetwork sitesi. https://ecotopianetwork.wordpress.com/2009/12/21/derin-ekoloji-hareketi-vecevre-etigi/ (Erişim 6 Mart 2017).

Çişti, Sadiye Hawar Han. "Fıtrat: İnsanlar ve Çevre İçin Bir İslâmi Model”. Richard C. Foltz, Frederick M. Denny ve Azizan Baharuddin (der.). İslam ve Ekoloji: Bahşedilmiş Bir Emanet. Çev. Nurettin Elhüseyni. İstanbul: Oğlak Yayıncılık, 2007: 67-87. 
Doğru, Barış. Umudu Yeşertenler: Ekoloji Söyleşileri. İstanbul: Optimist Yayınları, 2009.

Dönmez, Süleyman ve Mehmet Ali Çelik. "Ekolojik Krizin Kaynağını İnsan Olarak Gören İndirgemeci Anlayışın Eleştirisi”. Çukurova Üniversitesi İlahiyat Fakültesi Dergisi. 16/2 (2016): 39-51.

Dönmez, Süleyman. Emanet Ahlakı. Adana: Karahan Kitabevi, 2015.

Dönmez, Süleyman. Keşfedilmeyi Bekleyen Medeniyet: Felsefenin Batı Dışı Referanslarına Eleştirel Bir Katkı. Adana: Karahan Kitabevi, 2015.

Dursunoğlu, İsmail. "Sosyal Darwinizm”. Karabük Üniversitesi Sosyal Bilimler Enstitüsü Dergisi. 6/1 (2016): 210-221.

“Ganj nehri artık insan haklarına sahip”. BBC Türkçe internet sayfası. 23 Mart 2017. http://www.bbc.com/turkce/haberler-dunya-39342778 (Erişim 5 Haziran 2017).

Giddens, Anthony. İklim Değissimi ve Siyaseti. Çev. Erhan Baltacı. İstanbul: Phoenix, 2013.

Harvey, David. Umut Mekanları. Çev. Zeynep Gambetti. İstanbul: Metis Yayınları, 2008.

Karaca, Coşkun. "Çevre, İnsan ve Etik Çerçevesinde Çevre Sorunlarına ve Çözümlerine Yönelik Yaklaşımlar”. Çukurova Üniversitesi İİBF Dergisi. 11/1 (2007): 1-19.

Kılınç, Aygül. "Neoliberalizm Bağlamında Sürdürülebilir Kalkınmanın Merkez ve Çevre Ülkeler Açısından Değerlendirilmesi”. Afyon Kocatepe Üniversitesi İİBF Dergisi. 14 (1) 2012: 147-161.

Kocataş, Ahmet. Ekoloji: Çevre Biyolojisi. Bursa: Dora Basım, 2014.

Meriç, Cemil. Bir Dünyanın Eşiğinde. İstanbul: İletişim Yayınları, 1994.

Özel, Mehmet. "Çağımız Çevre Sorunlarının Düşünsel Temelleri Üzerine Bir Yaklaşım”. Gazi Üniversitesi iktisadi ve İdari Bilimler Fakültesi Dergisi. 9/1 (2007): $207-226$.

Ülken, Hilmi Ziya. Aşk Ahlakı, İstanbul: Türkiye İş Bankası Kültür Yayınları, 2010.

Yalçın, Mehmet ve Fatma Ağgül. “Collingwood’un 'Doğa Tasarımı' ve Fen Eğitimi için Doğurguları”. Gazi Eğitim Fakültesi Dergisi. 29/2 (2009): 295-310. 


\title{
Human-Nature Relationships within the Triangle of Commensalism, Mutualism and Parasitism
}

\begin{abstract}
There are various types of symbiotic interactions among living beings in non-human nature. While sometimes these interactions are for the benefit of both organisms in a relationship, sometimes one of the organisms in a relationship suffers. All of these relationships in general, are called symbiosis. Symbiosis is seen in three different ways which are commensalism, mutualism and parasitism. This study readdresses human-nature relationships within the context of mutualism without eliminating the bridges between logos and nous in onto-epistemic respect. The conception which does not understand the nous-logos dialect on the journey from nous to logos axis seeks for a solution to the ecological crisis by means of absolute mechanical solutions such as reducing amount of carbon in the atmosphere, use of home appliances consuming less energy etc. Though, such mechanical solution suggestions based on logos perception which lack nous, deepen the problem lasting for centuries rather than solving it. In our day, it is necessary to make the concept of from oneness to togetherness predominant in order for human-nature relationships not to lead further crisis. When togetherness from oneness or oneness from togetherness is understood, the path of togetherness will be cleared. The other, i.e. the nature will be noticed in this way, and communication through Ethics (moral) will be achieved.
\end{abstract}

Keywords: Ecological crisis, Ethics, Human-nature relationships, Logos, Nous. 